\title{
THE VAT TREATMENT OF CRYPTOCURRENCIES IN SOUTH AFRICA: LESSONS FROM AUSTRALIA*
}

\author{
Ruddy Kabwe \\ LLB LLM \\ Doctoral Student, Department of Mercantile Law, \\ University of Pretoria
}

\section{SUMMARY}

Cryptocurrencies are revolutionary digital currencies used by people on a peer to peer network. Cryptocurrencies are predominantly used as a payment method in business transactions. However, challenges arise with cryptocurrency borne transactions due to the lack of universal accepted classification of cryptocurrencies, the result of which leads to unintended tax consequences for cryptocurrency users. This article examines the recent amendment to the Value-Added Tax (VAT) 89 of 1991 pertaining specifically to the VAT treatment of cryptocurrencies in South Africa. Currently, transactions in cryptocurrencies are deemed to be financial services in South Africa. This means that a supply of any cryptocurrency in South Africa is exempt from VAT. This article makes a comparison with the Australian legislative framework to determine how cryptocurrencies are treated for VAT/GST purposes in that country. Although the move to regulate cryptocurrencies is welcomed, this article argues that cryptocurrency activities are incorrectly legislated as financial services in the VAT Act.

\section{$1 \quad$ INTRODUCTION}

Since its inception in 2009, cryptocurrencies have revolutionised money markets, the financial sector and electronic commerce transactions while potentially creating new business models in the process. The idea of using a perceived digital decentralised currency as a payment method in exchange for goods and services has proven to be indispensable for individuals and businesses. However, part of the challenge with cryptocurrency-borne transactions is the seemingly lack of an appropriate uniform legislative framework addressing the risks and tax implications thereof. This is compounded by a lack of universal classification of cryptocurrencies, leading to unintended tax consequences for cryptocurrency users and merchants.

Paper presented at the $6^{\text {th }}$ Annual International Mercantile Law Conference, University of the Free State (7 November 2019). 
For any government to do its core functions efficiently, it requires revenue. The revenue collected is generated from taxes with the aim of addressing core functions such as financing public expenditure and promoting socioeconomic growth. ${ }^{1}$ It is trite that states need additional streams of revenue and improved revenue systems. ${ }^{2}$ The reality is that imposing taxes on economic activity is one of the most efficient ways for governments to raise revenue. It stands to reason that tax authorities should endeavour to broaden the tax base in order to increase the revenue pool. ${ }^{3}$

The advent of the Taxation Laws Amendment Act 23 of 2018 introduced changes to the Value-Added Tax 89 of 1991 (the VAT Act) in so far as cryptocurrencies are concerned. In terms of the VAT Act, cryptocurrencies are deemed to be financial services and therefore exempt from VAT. ${ }^{4}$

The purpose of this article is to argue for the treatment of cryptocurrencies as taxable supplies for VAT purposes. To support this argument, the article explores the Australian legislative framework that specifically deals with the VAT/Goods and Services Tax (GST) ${ }^{5}$ treatment of cryptocurrencies. The way Australia treats cryptocurrencies can be used as a model for the VAT treatment of cryptocurrencies in South Africa. Australia is selected as a comparative country as it currently has the most comprehensive guidelines and legislation pertaining to the VAT/GST treatment of cryptocurrencies.

This article concludes by making recommendations for the treatment of cryptocurrencies as a taxable supply for VAT purposes.

In this article "cryptocurrencies" and "Bitcoin" are used interchangeably.

\section{THE CHARACTERISTICS OF CRYPTOCURRENCIES}

The success and popularity of cryptocurrencies has largely been attributed to two important aspects. Firstly, cryptocurrency transactions are anonymous in nature. Users buy, sell and exchange cryptocurrencies with other users without revealing one's identity. Secondly, transactions involving cryptocurrencies do not incur any fees. ${ }^{6}$ The lack of fees translates into significantly lower transaction costs because users transact with each other without the aid of an intermediary. ${ }^{7}$

Croome, Oguttu, Muller, Legwaila, Williams, Kolitz and Louw Tax Law An Introduction (2013) 8.

2 Bird and Gendron The VAT in Developing and Transitional Countries (2007) 8.

3 There is a caveat to this, however. When considering an expansion of the tax base, it is important to consider the principles of taxation like certainty, convenience, equity, cost effectiveness and efficiency.

4 S 2 of the VAT Act.

5 GST and VAT are used interchangeably throughout this article.

6 Bal "Taxing Virtual Currency: Challenges and Solutions" 2015 43(5) Intertax 381. See also Van Alstyne "Why Bitcoin has Value: Evaluating the Evolving Controversial Digital Currency" 2014 57(5) Communications of the ACM Journal 3030.

7 Brito, Anning, Friedman, Taylor, Strauss, Brazell, Von Unruh, Brailsford, Cleary and Hoegner The Law of Bitcoin (2015) 7. 
The growth of cryptocurrencies has been precipitated by what is known as the network effect. ${ }^{8}$ What this means in simple terms, is that the more people use and exchange cryptocurrencies (such as bitcoins) in the digital currency sytem, ${ }^{9}$ the more valuable the cryptocurrency (Bitcoin) becomes. ${ }^{10}$ The reason cryptocurrencies have value is because people receive and use it as a form of money. ${ }^{11}$ However, cryptocurrencies have a tendency to fluctuate due to uncertainty regarding its value and the attempts by jurisdictions to regulate it. ${ }^{12}$ According to Blundell-Wignall, the reason for bitcoins' volatility is that:

"There is no clear intrinsic value or agreed valuation method, and certainly no Bitcoin central bank prepared to intervene to make the price more stable, which would violate the fixed supply element."13

The volatility component creates uncertainty for potential users, investors, businesses, governments and tax authorities. Due to its volatility, Nabilou argues that the use of cryptocurrencies as a unit of account will be difficult. ${ }^{14}$ For this reason, Nabilou also argues that it is preferable for individuals to use cryptocurrencies as a store of value (an asset) as opposed to a unit of account. ${ }^{15}$

Regulation of cryptocurrencies remains one of the most difficult challenges for governments and tax authorities. This is because transactions involving cryptocurrencies do not require the intervention or facilitation of third parties. Instead, cryptocurrencies are created and exchanged through a decentralised global network. ${ }^{16}$ The decentralised global network is not controlled by any government or state.

\section{UNDERSTANDING THE NATURE OF CRYPTOCURRENCIES}

From the outset, it is important to understand and define cryptocurrencies. In as much as governments and tax authorities seek to regulate cryptocurrencies, comprehensive regulation cannot properly take place if the

8 Bashir Mastering Blockchain: Distributed Ledgers, Decentralization and Smart Contracts Explained (2017) 115.

9 It should be noted that "Bitcoin" with a capital "B" refers to the cryptocurrency as a brand of digital currency as opposed to other cryptocurrency brands such as Litecoin, Ethereum and Tether whereas "bitcoin" with a lower case "b" refers to the denomination of the Bitcoin cryptocurrency in use.

10 Bashir Mastering Blockchain: Distributed Ledgers, Decentralization and Smart Contracts Explained 115.

11 Van Alstyne 2014 Communications of the ACM Journal 30.

12 Callahan "The Bitcoin Price is Fluctuating: What Are the Reasons?" (6 June 2018) https://www.coinspeaker.com/bitcoin-price-fluctuating-reasons/ (accessed 2019-06-03).

13 Blundell-Wignall "The Bitcoin Question: Currency Versus Trust-Less Transfer Technology" 201437 OECD Working Papers on Finance, Insurance and Private Pensions 8.

14 Nabilou and Prum "Ignorance, Debt and Cryptocurrencies: The Old and the New in the Law and Economics of Concurrent Currencies" (2018) Journal of Financial Regulation http://orbilu.uni.lu/bitstream/10993/38830/1/SSRN-id3121918.pdf (accessed 2019-07-22) 7.

15 Ibid.

16 The original decentralised global network is known as "Bitcoin" with a capital "B". 
same governments and tax authorities do not adequately understand the nature and activities relating to cryptocurrencies. ${ }^{17}$ It is quite likely that jurisdictions interpret the meaning of cryptocurrencies differently and the result is a lack of uniformity on the VAT treatment for cryptocurrencies.

The term cryptocurrency is often used to denote "virtual currency". A cryptocurrency is a maths-based decentralised convertible virtual currency that is protected by cryptography. ${ }^{18}$ From this definition, it can be said that a cryptocurrency is a subdivision of a virtual currency. ${ }^{19}$ The Financial Action Task Force (FATF ${ }^{20}$ defines a virtual currency as a digital representation of value that is traded digitally and has one or more of the following characteristics: a medium of exchange, a unit of account and a store of value. ${ }^{21}$ In other words, the existence of virtual currency is largely dependent on the Internet because virtual currencies are digital in nature. Although virtual currencies may be used as a medium of exchange and they appear to have all the characteristics of money, ${ }^{22}$ it does not necessarily follow that virtual currency is legal tender ${ }^{23}$ unless it is duly issued and authorised by a state's central bank. Virtual currencies on the other hand, are issued by individuals on a peer-to-peer network. In South Africa, legal tender is only issued by the South African Reserve Bank (SARB). ${ }^{24}$ Although the term "legal tender" is not specifically defined in the South African Reserve Bank Act 90 of 1989, it is generally accepted to mean coins, bank notes and gold coins. ${ }^{25}$

A distinction must be drawn between virtual currency and fiat money. Fiat money includes bank notes, coins and any legal tender issued by a jurisdiction. Fiat money, however, is often also colloquially referred to as "electronic money" or "e-money" because it is capable of being represented

17 Bal "Developing a Regulatory Framework for the Taxation of Virtual Currencies" 2019 47(2) Intertax 224.

18 Financial Action Task Force (FATF) "FATF Report Virtual Currencies Key Definitions and Potential AML/CFT Risks" (2014) https://www.fatf-gafi.org/media/fatf/documents/reports/ Virtual-currency-key-definitions-and-potential-aml-cft-risks.pdf (accessed 2019-05-28) 5; see also Bal 2019 Intertax 219 at fn 2.

19 Bal 2019 Intertax 219 at fn 2.

20 The Financial Action Task Force (FATF) is an inter-governmental body established in 1989 by the Ministers of its Member jurisdictions. The objectives of the FATF are to set standards and promote effective implementation of legal, regulatory and operational measures for combating money laundering, terrorist financing and other related threats to the integrity of the international financial system. The FATF is therefore a "policy-making body" which works to generate the necessary political will to bring about national legislative and regulatory reforms in these areas, https://www.fatf-gafi.org/about/ (accessed 2019-07-15).

21 FATF https://www.fatf-gafi.org/media/fatt/documents/reports/Virtual-currency-key-definitions -and-potential-aml-cft-risks.pdf; see also Brito et al The Law of Bitcoin 2-3; Lyndell Virtual Currencies: Regulatory and Tax Compliance Issues (2014) 7.

22 Characteristics of money include: (1) medium of exchange (2) store of value (3) unit of account (4) legal tender (5) standard of deferred payment (6) liquidity (7) stability of value (8) interchangeable (9) portability and (10) confidence, https://simplicable.com/new/money (accessed 2019-07-15).

23 FATF https://www.fatf-gafi.org/media/fatt/documents/reports/Virtual-currency-key-definitions -and-potential-aml-cft-risks.pdf 4; see also Brito et al The Law of Bitcoin 3.

24 S 10(1)(iii) of the South African Reserve Bank Act 90 of 1989.

$25 \mathrm{~S} 17$ of the South African Reserve Bank Act 90 of 1989. 
digitally. ${ }^{26}$ Because of this digital representation, virtual currency and fiat money are often referred to as "digital currencies". By definition, a digital currency is a digital representation of virtual and fiat currencies. ${ }^{27} \mathrm{~A}$ virtual currency can further be subdivided into convertible and non-convertible virtual currencies. For instance, bitcoins can have a value in South African Rand (the Rand) and it can be exchanged for the Rand at any given time. For this reason, bitcoins is an example of a convertible virtual currency. On the other hand, a non-convertible currency "is intended to be specific to a particular virtual domain or world". ${ }^{28}$ Typical examples of non-convertible currencies include World of Warcraft Gold and Q Coins. ${ }^{29}$

Furthermore, convertible virtual currencies can be divided into centralised and decentralised virtual currencies. A virtual currency is centralised if it has a central administrator that is responsible for issuing the currency; the administrator establishes the rules of the currencies' use and the administrator maintains a payment ledger. ${ }^{30} \mathrm{~A}$ decentralised currency, as the name suggests, has no central authority and no central monitoring oversight. ${ }^{31}$ The most well-known decentralised currency is bitcoin.

\section{$4 \quad$ WHAT IS BITCOIN?}

Introduced in 2009 by a programmer using the pseudonym Satashi Nakamoto, bitcoin is an international, decentralised, convertible, virtual currency. ${ }^{32}$ Bitcoins consist of units of account comprised of numbers and letters that constitute units of the currency. ${ }^{33}$ Bitcoins, as a form of cryptocurrency, is traded digitally between users and they can also be exchanged into fiat currency (real money); bitcoins can be exchanged for other virtual currency; and bitcoins can be exchanged for goods and services. ${ }^{34}$ Brito et al summarise the characteristics of Bitcoin as a system that is peer to peer and computationally impractical to reverse; cryptographically secure and uses proof of work. ${ }^{35}$

Anyone can create bitcoins through a process called "mining". The mining of bitcoins involves creating new bitcoins by using computational power in

26 FATF https://www.fatf-gafi.org/media/fatf/documents/reports/Virtual-currency-key-definitions -and-potential-aml-cft-risks.pdf 4; see also Brito et al The Law of Bitcoin 3. Fiat money can also be represented digitally. For example, money can be transferred electronically by means of an electronic funds transfer (EFT).

27 Ibid.

28 Ibid.

9 Ibid.

30 FATF https://www.fatf-gafi.org/media/fatf/documents/reports/Virtual-currency-key-definitions -and-potential-aml-cft-risks.pdf 5.

Ibid.

Brito et al The Law of Bitcoin 7.

3 FATF https://www.fatf-gafi.org/media/fatf/documents/reports/Virtual-currency-key-definitions -and-potential-aml-cft-risks.pdf 3-6.

34 FATF https://www.fatf-gafi.org/media/fatf/documents/reports/Virtual-currency-key-definitions -and-potential-aml-cft-risks.pdf 6.

35 Brito et al The Law of Bitcoin 5. 
order to solve complex algorithms or puzzles. ${ }^{36}$ Once a miner ${ }^{37}$ has created new bitcoins, that miner is rewarded with what is known as "block reward" and transaction fees. The block reward consists of a specific number of bitcoins. ${ }^{38}$

One of the interesting aspects of utilising the Bitcoin system is that one does not need to register or provide their identity in order to conduct a transaction. All Bitcoin transactions are stored in the Bitcoin blockchain stored in a free and open-source software that is often known as the Bitcoin protocol. ${ }^{39}$ One merely accesses the Internet on a compatible device, downloads the free software and then stores, sends, receives and monitors Bitcoin transactions. ${ }^{40}$

Currently, the Organisation for Economic Cooperation and Development (OECD) has not prescribed any universal regulations or guidelines on the classification and VAT treatment of cryptocurrencies. However, the OECD, ${ }^{41}$ in its 2018 Report to G20 Finance Ministers and Central Bank Governors, stated:

"Given the availability of big data, international co-operation among tax authorities should be enhanced, in particular, as regards the information on the users of online platforms as part of the gig and sharing economies, to ensure taxes are paid when they are due. The forum on tax administration, working with the inclusive framework, will develop practical tools and cooperation in the area of tax administration and will also examine the tax consequences of new technologies like cryptocurrencies and blockchain." 42

This implies that the OECD is of the view that transactions involving cryptocurrencies should be subject to tax. However, the report does not specifically state how such transactions should be taxed. Nor does it give a pro forma legal framework for the taxation and VAT treatment of cryptocurrencies. The "how" is left to individual states to consider and establish appropriate regulatory framework for the tax consequences of cryptocurrencies.

36 FATF https://www.fatf-gafi.org/media/fatf/documents/reports/Virtual-currency-key-definitions -and-potential-aml-cft-risks.pdf 7; Bal 2015 Intertax 381.

37 An individual or entity that has special computer software that enables them to "create" new bitcoins.

38 De Filippi and Wright Blockchain and the Law: The Rule Code (2018) 25.

39 De Filippi and Wright Blockchain and the Law: The Rule Code 21.

40 FATF https://www.fatf-gafi.org/media/fatf/documents/reports/Virtual-currency-key-definitions -and-potential-aml-cft-risks.pdf 6.

41 South Africa is currently not a member of the OECD but interacts with subsidiaries of the organisation; see http://www.dirco.gov.za/foreign/Multilateral/inter/oecd.htm (accessed 2019-11-30).

42 OECD "OECD Secretary-General Report to G20 Finance Ministers and Central Bank Governors" (March 2018) http://www.oecd.org/ctp/OECD-Secretary-General-tax-reportG20-Finance-Ministers-Argentina-March-2018.pdf (accessed 2019-12-02) 9. 


\section{THE VAT TREATMENT OF CRYPTOCURRENCIES IN SOUTH AFRICA}

\section{A modern VAT system}

Before discussing the VAT treatment of cryptocurrencies in South Africa, it is important to understand how VAT works. VAT is a form of consumption tax. Although VAT is collected at each stage of production, the consumer is ultimately responsible for paying VAT. While the VAT liability is on the consumer, VAT is charged at each stage of production and distribution making it possible for businesses in the chain to deduct the VAT paid. ${ }^{43}$ The VAT deducted is also known as input tax. VAT is due when a consumer "pays" for the goods or services that they have acquired for personal use.44 Usually, a consumer receives an invoice with the purchase price that is inclusive of VAT. The VAT displayed on the invoice affords businesses the opportunity to recover VAT on their own purchases. ${ }^{45}$ This is known as the invoice method of accounting for VAT.

The conventional approach is for a seller to charge VAT on his or her taxable supplies (output tax) and then subsequently claim a credit for the purchase of the goods or services (input tax). The difference between the output tax and input is the VAT payable. If the input tax exceeds the output tax, then a refund can be claimed. The collection of VAT during the various stages of production indicates that VAT is a form of tax introduced with the objective of raising revenue. ${ }^{46}$

In South Africa, VAT is levied on the importation of goods; on the supply of imported services and on the supply of goods and services by a vendor in the furtherance of his or her enterprise. ${ }^{47}$ Although not explicitly stated in the VAT Act, South Africa adopts the destination principle as opposed to the origin principle ${ }^{48}$ as means to tax consumption. In terms of the destination principle, the taxation of goods and services takes place in the country where these goods are services are "used". In other words, all exports are free from VAT while imports are subject to VAT.

The destination principle is particularly important where services (electronic services) are purchased and thereafter supplied from traders that

43 Silver and Beneke Deloitte VAT Handbook 10ed (2015) 3.

44 Ibid.

45 Kerrigan "The Elusiveness of Neutrality - Why is it so Difficult to Apply VAT to Financial Services?" 2010 Munich Personal Research Papers in Economics Archive https://mpra.ub. uni-muenchen.de/22748/1/MPRA_paper_22748.pdf (accessed 2019-12-01) 4.

46 Bal Taxation of Virtual Currency (PhD thesis, University of Leiden) 2014202.

$47 \mathrm{~S} 7(1)(a)$ to $(c)$ of the VAT Act. An "enterprise" is defined as "any enterprise or activity which is carried on continuously or regularly by any person in the Republic or partly in the Republic and in the course or furtherance of which goods or services are supplied to any other person for a consideration, whether or not for profit, including any enterprise or activity carried on in the form of a commercial, financial, industrial, mining, farming, fishing, municipal or professional concern or any other concern of a continuing nature or in the form of an association or club."

48 In terms of this principle, taxation of goods and services takes place in the country where they are produced. 
are located outside the borders of South Africa (cross-border electronic commerce transactions). Sometimes, it is impossible to establish the location or the area where the services ${ }^{49}$ are consumed. ${ }^{50}$ This is due to various reasons, but the most crucial aspect is the inability to identify the consumer. As a result of this, tax authorities insert proxies in legislation as aids to determine the location of the consumer. ${ }^{51}$

\section{Cryptocurrencies and the VAT Act}

Currently, the VAT Act does not define cryptocurrencies. It appears that the relevant policy makers did not consider the importance of including a legal definition of cryptocurrencies in the VAT Act. A lack of a definition in the VAT Act creates uncertainty for taxpayers and the general public because compliance with any tax legislation is dependent on the understanding of the relevant legal provision in any tax legislation. By the same token, if a taxpayer does not understand the meaning of the terms in a tax legislation or if the term is vague; it is difficult for a taxpayer to comply with the necessary legislation. This challenge is compounded by the fact that there is a plethora of information about cryptocurrencies on the Internet. Accessing different websites may result in a taxpayer formulating his or her own opinion about what constitutes cryptocurrencies; in the absence of any legislated definition of the said term in the VAT Act. For example, the word "cryptocurrency" can often be used interchangeably to denote "bitcoin", "currency", "money" and even "tokens". ${ }^{52}$ All these terms have different connotations which may or may not necessarily be attributed to a legal definition of cryptocurrencies. Furthermore, Bitcoin is not the only form of a decentralised cryptocurrency. ${ }^{53}$ To avoid uncertainty, a definition of cryptocurrency must be adopted in the VAT Act.

\section{Financial services and cryptocurrencies}

Section 2 of the VAT Act defines the term "financial services" as:

"(1) For the purposes of this Act, the following activities shall be deemed to be financial services:

(a) The exchange of currency (whether effected by the exchange of bank notes or coin, by crediting or debiting accounts, or otherwise);

(b) the issue, payment, collection or transfer of ownership of a cheque or letter of credit;

(c) the issue, allotment, drawing, acceptance, endorsement or transfer of ownership of a debt security;

49 This is because services are intangible in nature making the traceability thereof impractical.

50 Kabwe Consumption Tax Collection Models in Online Trade in Digital Goods (unpublished LLM mini-dissertation, UNISA) 2017 27; Bal Taxation of Virtual Currency 204.

51 See s 1 part (vi)(aa) to (cc) of the definition of "enterprise" in the VAT Act. Currently, South Africa uses the bank details, address and residency status of the consumer as proxies for the supply of electronic services.

52 Bal 2019 Intertax 225.

53 Others include Litecoin, Ethereum, Dash and Monero. 
(d) the issue, allotment or transfer of ownership of an equity security or a participatory security;

(e) $\ldots$...

(f) the provision by any person of credit under an agreement by which money or money's worth is provided by that person to another person who agrees to pay in the future a sum or sums exceeding in the aggregate the amount of such money or money's worth;

(g) $\ldots$...

(h) $\quad \cdots .$.

(i) the provision, or transfer of ownership, of a long-term insurance policy or the provision of reinsurance in respect of any such policy: Provided that such an activity shall not be deemed to be a financial service to the extent that it includes the management of a superannuation scheme;

(j) the provision, or transfer of ownership, of an interest in a superannuation scheme;

(k) the buying or selling of any derivative or the granting of an option:

Provided that where a supply of the underlying goods or services takes place, that supply shall be deemed to be a separate supply of goods or services at the open market value thereof:

Provided further that the open market value of those goods or services shall not be deemed to be consideration for a financial service as contemplated in this paragraph;

(l) $\quad \ldots$.

(m) $\ldots$

(n) $\quad \ldots .$.

(o) the issue, acquisition, collection, buying or selling or transfer of ownership of any cryptocurrency."

The implication of this provision has the effect of rendering supplies of cryptocurrencies as VAT exempt in South Africa. ${ }^{55}$ A resident who supplies or sells any cryptocurrency may not charge any output VAT on that transaction. Similarly, a vendor ${ }^{56}$ cannot claim an input tax deduction on any subsequent purchase of the cryptocurrency. Although it is not explicitly stated in the VAT Act, it is submitted that this provision also applies to business to business transactions. A business that transfers cryptocurrencies to another business will not be required to account for VAT on that transaction. While the cross-border trade of cryptocurrencies is also currently not addressed in the VAT Act, it is submitted that these transactions are likewise exempt from VAT.

\section{An analysis of the classification of cryptocurrency activities as financial services}

Currently, there is no universal accepted definition of financial services for VAT purposes. As a result, states and tax authorities use their discretion in

54 Emphasis added.

$55 \mathrm{~S} 12(\mathrm{a})$ of the VAT Act.

56 A vendor is a person that is required to be registered in terms of the VAT Act. A person is obligated to register as a vendor at the end of a month where the total value of the taxable supplies exceeds R1 million in the preceding 12 months. See s 1 of the definition of "vendor" read with s 23(1)(a) of the VAT Act. 
their respective legislative framework in order to establish activities that constitute financial services. The conventional approach is to define financial services by giving examples of the activities that comprise financial services in a form of a list. For instance, the VAT Act does not explicitly define "financial services" but itemises services, such as the exchange of money or the issue of a debt security instrument, in the definition of financial services. ${ }^{57}$ In Australia, a similar approach is followed where financial supplies (financial services) are not specifically defined in the legislative framework. ${ }^{58}$ Instead, financial supplies are itemised in the Regulations to the GST Act (the Regulations). ${ }^{59}$ Interestingly, the Regulations specifically list items that constitute financial supplies and items that do not constitute financial supplies. 60 This is in contrast to the VAT Act which merely lists services that constitute financial services for VAT purposes. It is submitted that the rationale for inserting provisions in the regulations of an enabling Act as opposed to a specific legislation is to enable legislators to easily effect the necessary changes without going through the perceived tedious process of amending the relevant legislation.

It is unclear why there is a lack of consensus on the definition of financial services. As the term suggests, financial services are services that relate to the financial sector. Services in the financial sector include banking, insurance, investments and the financial market. In its simplest from, financial services are transactions that involve the exchange of money against money. ${ }^{61}$ At the core of these transactions is the role that a bank plays as an intermediary. Banks play a crucial role when, for instance, an investor deposits funds which are then required by a borrower. ${ }^{62}$ If one considers that financial services use intermediaries and in most cases banks, it becomes apparent that there is no nexus between cryptocurrencies and its classification as a financial service in the VAT Act. The lack of a nexus renders the current framing of cryptocurrency activities in the VAT Act devoid of any existential meaning because cryptographic transactions do not make use of banks as intermediaries. Furthermore, it is accepted that cryptocurrencies do not comply with the definition of "money" for VAT purposes. Currently, banks do not lend cryptocurrencies as "money" to borrowers. ${ }^{63}$ This then raises an important question as to why tax authorities in South Africa elected to classify an activity involving cryptocurrencies as a financial service.

To the author's knowledge, no written reasons were submitted by National Treasury or SARS pertaining to the VAT treatment of cryptocurrency

57 S 2 of the VAT Act.

58 See the definition of "financial supply" in s 40-5 of the GST (A New Tax System) Act regulations 1999 compilation 38 .

59 S 40-5.09 of the GST (A New Tax System) Act regulations 1999 compilation 38.

60 S 40-5.10 read with S 40-5.11 and Schedule 2 of the GST (A New Tax System) Act regulations 1999 compilation 38 .

61 Kerrigan https://mpra.ub.uni-muenchen.de/22748/1/MPRA_paper_22748.pdf 1.

62 James The Rise of the Value-Added Tax (2015) 62.

63 Even if banks do lend cryptocurrencies as "money", the cryptocurrencies will not be considered as legal tender unless it is specifically recognized as such by a state's central bank. 
dealings as a "financial service" for VAT purposes. The only previous known communiqué to the author was an official statement released on 6 April 2018 by SARS on its website. ${ }^{64}$ The statement, while it attempted to guide taxpayers on the income tax treatment of cryptocurrencies, read as follows in relation to VAT and cryptocurrencies:

"The 2018 annual budget review indicates that the VAT treatment of cryptocurrencies will be reviewed. Pending policy clarity in this regard, SARS will not require VAT registration as a vendor for purposes of the supply of cryptocurrencies."

Subsequent to this statement, no further official announcements pertaining to the VAT treatment of cryptocurrencies were communicated to the general public. Similarly, the relevant tax authorities did not provide any reasons for rendering the supply of cryptocurrencies as VAT exempt. ${ }^{65}$ It is generally accepted that supplies of financial services are exempt from VAT. However, there is a view that financial services should be subject to VAT.66 The argument for subjecting financial services to VAT emanates from a need to broaden the tax base. Another reason that supports the view that financial services should be subject to VAT is that not subjecting financial services to VAT compromises the neutrality of tax leading to market distortions. ${ }^{67}$ The arguments supporting the exemption of financial services becomes apparent when it becomes difficult to ascertain the value of the services on a transactional basis 68 and the administrative complexities involved in identifying the actual value of the service element that is part of a margin. ${ }^{69}$

While it is conceded that a possible rationale for rendering supplies of cryptocurrencies as VAT exempt is because there is no actual "value added", ${ }^{70}$ it does not necessarily follow that cryptocurrency activities are financial services. It is submitted that the tax authorities' classification of cryptocurrencies as a financial service has more to do with the perceived nature of cryptocurrencies as opposed to its potential use as a source of revenue.

64 SARS "SARS's Stance on the Tax Treatment of Cryptocurrencies" (6 April 2018) https://www.sars.gov.za/Media/MediaReleases/Pages/6-April-2018---SARS-stance-on-thetax-treatment-of-cryptocurrencies-.aspx (accessed 2019-07-16).

65 See the Explanatory Memorandum on the Taxation Laws Amendment Bill, Act 23 of 2018

66 See Tait Value Added Tax: International Practice and Problems (1998) 93; Prebble and Van Schalkwyk "VAT and Financial Services" 201329 Victoria University of Wellington Legal Research Papers 363 365; Kerrigan https://mpra.ub.uni-muenchen.de/22748/1/ MPRA paper_22748.pdf 1

67 Kerrigan https://mpra.ub.uni-muenchen.de/22748/1/MPRA_paper_22748.pdf 1.

68 James The Rise of the Value-Added Tax 61.

69 Bird and Gendron The VAT in Developing and Transitional Countries 98; James The Rise of the Value-Added Tax 61-62; Ebrill, Keen, Bodin and Summers The Modern VAT (2001) 94-95; Prebble and Van Schalkwyk 2013 Victoria University of Wellington Legal Research Papers 365.

70 When a person mines, issues, sells, buys or even exchanges cryptocurrencies. Simply put, at no stage during the 'production' of cryptocurrencies does the creator add value to the same cryptocurrency before selling it to potential buyers. 


\section{Mining cryptocurrencies and VAT}

\section{Is it a service?}

An important aspect that needs exploration is whether the process of creating cryptocurrencies, that is bitcoin mining, qualifies as a service for VAT purposes. Bitcoin mining is not specifically addressed in the VAT Act. If one considers that a person creates new bitcoins during the mining process, then that person is rendering a service for VAT purposes. It is submitted that the definition of services in the Act is sufficiently broad to include bitcoin mining. This viewpoint is supported by Bal. ${ }^{71}$

\section{Is it a taxable supply?}

Having established the classification of bitcoin mining as a service for VAT purposes, it must be established whether the supply of bitcoin mining is a taxable supply. Generally, a supply is taxable if VAT is charged at a rate of fifteen per cent on that transaction. ${ }^{72}$ Since the supply of cryptocurrencies is VAT exempt, then it follows that bitcoin mining is not a taxable supply. Bal correctly points out that the liability for VAT is contingent on the establishment of a reciprocal legal relationship between the provider of the services and the recipient of those services. ${ }^{73}$ In the context of bitcoin mining, no person "consumes" the proceeds thereof. If there is indeed a consumer, identifying that consumer would be unrealistic. For this reason, bitcoin mining does not incur any VAT liability.

\section{Cryptocurrencies as a payment method}

Bitcoin was originally designed as an alternative payment method to traditional payment methods. ${ }^{74}$ Bitcoin's popularity led to increase usage by merchants and other businesses. Low transaction costs, instantaneous payments and unlimited territorial application are some of the reasons for bitcoin's success. ${ }^{75}$ It is possible that Bitcoin will be accepted as a valid payment system if merchants continue to accept it as form of payment for goods and services. ${ }^{76}$ For this reason, it can be argued that whenever local merchants and vendors receive bitcoins as a form of payment for goods and services then that transaction should be treated as a taxable supply. For example:

Bal 2015 Intertax 386.

$\mathrm{S} 1$ of the definition of "taxable supply" in the VAT Act.

Bal 2019 Intertax 222-223.

Shcherbak "How Should Bitcoin be Regulated?" 2014 European Journal of Legal Studies 7 46.

75 Ibid.

76 Alcorn, Eagle and Sherbondy "Legitimizing Bitcoin: Policy Recommendations" 2013 http://groups.csail.mit.edu/mac/classes/6.805/student-papers/fall13-papers/bitcoin.pdf (accessed 2018-07-27) 6. 
$X Y Z$ is a resident e-commerce company selling goods and services on the Internet. $X Y Z$ regularly receives and accepts bitcoin payment from consumers in exchange of goods and services. $X Y Z$ converts the bitcoins into Rands. YYZ is a registered VAT vendor.

The implication of this transaction is that the VAT vendor in the above scenario must account for fifteen per cent VAT on transactions where bitcoins are accepted as a form of payment for goods and services. The onus rests on the vendor to collect and remit VAT on those transactions to SARS. ${ }^{77}$ The acceptance and subsequent conversion of bitcoins into the Rand equivalent effectively renders the transaction into a taxable supply. When issuing a tax invoice, a merchant or vendor must display the Rand value of the cryptocurrencies at the time the invoice is issued or at the time the vendor receives payment in cryptocurrencies. ${ }^{78}$ This implies that the merchant or vendor must establish the relevant exchange rate to convert the cryptocurrencies to Rand at the time the cryptocurrencies are received as payment or at the time the tax invoice is issued whichever time comes first. ${ }^{79}$

The effect of transactions akin to these effectively treats bitcoin payments as a consideration in money for VAT purposes. ${ }^{80}$ The definition of "money" specifically excludes any cryptocurrencies. The primary reason for this is that, despite having all the features of money, cryptocurrencies are not issued by the South African Reserve Bank. ${ }^{81}$

It is submitted that the treatment of cryptocurrencies as a taxable supply in the vendor's hands is important for three reasons. Firstly, it implies that a non-registered person accepting cryptocurrencies as a payment method and carrying on an enterprise becomes liable to register at the end of the month when the taxable supplies exceed $\mathrm{R} 1$ million in a 12-month period. The registration requirement applies to taxable supplies consisting of goods and services where cryptocurrencies are accepted as a payment method. ${ }^{82}$ Secondly, it becomes easier for the relevant tax authorities to audit VAT vendors as opposed to private individuals. The audit function works as an incentive for businesses and vendors to comply with VAT laws in order to

$S 14(1)(a)$ and $(b)$ of the VAT Act.

S 20(4) read with s 9(1) of the VAT Act.

79 See $s$ 9(1) of the VAT Act. This also highlights bitcoin's volatility since its value is determined by supply and demand.

80 The definition of "consideration" is quite broad. It denotes "in relation to the supply of goods or services to any person, includes any payment made or to be made (including any deposit on any returnable container and tax), whether in money or otherwise, or any act or forbearance, whether or not voluntary, in respect of, in response to, or for the inducement of, the supply of any goods or services, whether by that person or by any other person, but does not include any payment made by any person as a donation to any association not for gain: Provided that a deposit (other than a deposit on a returnable container), whether refundable or not, given in respect of a supply of goods or services shall not be considered as payment made for the supply unless and until the supplier applies the deposit as consideration for the supply or such deposit is forfeited." In addition, a consideration in money means a consideration expressed as money. See $s 1$ of the definition of "consideration" and "consideration in money" in the VAT Act.

81 See $s$ of the definition of "money" in the VAT Act.

82 See the definition of "supply", "enterprise" read with s 23(1) of the VAT Act. 
avoid fines and penalties. Thirdly, additional revenue is collected by vendors broadening the tax base in the process.

\section{Sale and trade of bitcoins}

It is important to consider if the sale and trade in bitcoins incurs any VAT liability for VAT vendors. Generally, a vendor incurs VAT liability when they supply goods and services in the furtherance of his or her enterprise. ${ }^{83} \mathrm{~A}$ vendor selling bitcoins in the furtherance of his or her enterprise will not incur any VAT liability for those transactions. Similarly, the buyer of those cryptocurrencies incurs no VAT liability. ${ }^{84}$ Often, these buyers purchase cryptocurrencies as a form of investment or for trading purposes. Bitcoins can be acquired on various platforms including from peers on the Bitcoin protocol, cryptocurrency trading platforms and cryptocurrency vending machines. ${ }^{85}$

\section{VAT/GST TREATMENT OF CRYPTOCURRENCIES IN AUSTRALIA}

\section{Background}

In 2014, the Australian Tax Office (ATO) released a Goods and Services Tax General Ruling (GSTR) pertaining to transactions involving bitcoins. ${ }^{86}$ Public Rulings are ATO's interpretation of the law. If a person or business makes use of a Ruling, ATO applies the law as expressed in the Ruling and binds both ATO and the taxpayer. A taxpayer does not incur any tax penalties for applying the provisions in the Ruling. ${ }^{87}$

According to the Ruling, ${ }^{88}$ the supply of bitcoins was not a financial supply for GST purposes; although a supply of bitcoins gave rise to GST liability. 89 However, concerns relating to double taxation arose due to ATO's GST treatment of bitcoins. For example, the acquisition of bitcoins with Australian dollars (a supply of bitcoins in exchange for money) by an Australian resident was subject to GST. If a resident proceeds to purchase goods and services with those bitcoins, that transaction was likewise susceptible to GST. 90 This was because ATO treated bitcoins as intangible property. The result was that taxpayers were liable for GST twice. ${ }^{91}$

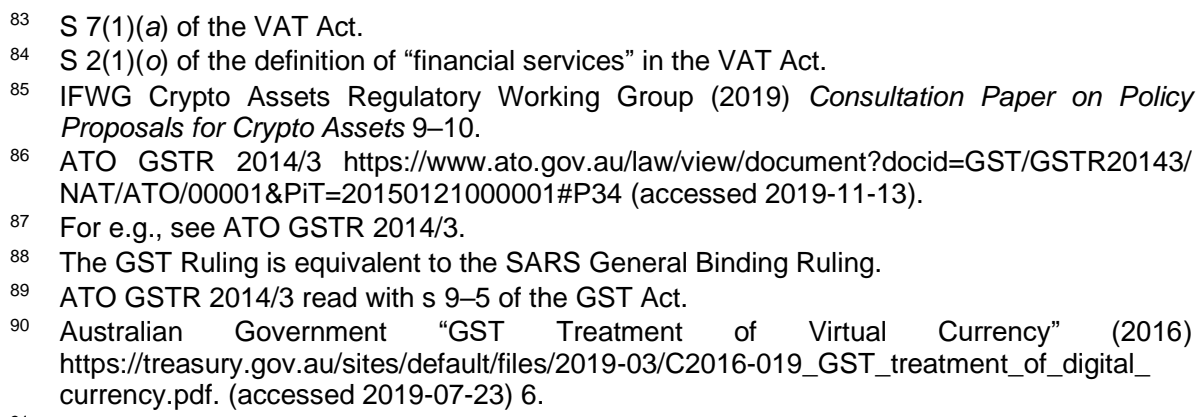




\section{A new position}

As a result of the implications of the double taxation, the ATO and the Australian government made changes to the GST treatment of cryptocurrencies. GSTR 2014/3 was subsequently withdrawn in December 2017.

Legislative changes in the form of the Treasury Laws Amendment Act (Measures No. 6) Act of 2017, assented to in October 2017, was promulgated. Although the Amendment Act was assented to in October 2017, ATO began treating transactions involving digital currencies as "money" effective 1 July 2017.92 The Amendment Act introduced a legal definition for digital currency ${ }^{93}$ in A New Tax System (Goods and Services Tax) Act (the GST Act) 1999.

\section{What is digital currency?}

According to the Treasury of the Australian government, the insertion of a legal definition for digital currency allows for a "precise set of criteria that avoids unintended outcomes." ${ }^{4}$ Providing a legal definition also enables the Australian tax authorities to cover GST treatment of digital currencies comprehensively, thus creating legal certainty in the process.

"Digital currency" is defined as:

Digital units of value that:

(a) are designed to be fungible; and

(b) can be provided as consideration for a supply; and

(c) are generally available to members of the public without any substantial restrictions on their use as consideration; and

(d) are not denominated in any country's currency; and

(e) do not have a value that depends on, or is derived from, the value of anything else; and

(f) do not give an entitlement to receive, or to direct the supply of, a particular thing or things, unless the entitlement is incidental to:

(i) holding the digital units of value; or

(ii) using the digital units of value as consideration;

but does not include:

(g) money; or

(h) a thing that, if supplied, would be a financial supply for a reason other than being a supply of one or more digital units of value to which paragraphs (a) to (f) apply. ${ }^{95}$

92 See https://ministers.treasury.gov.au/ministers/scott-morrison-2015/media-releases/ removing-double-taxation-digital-currency (accessed 2020-10-23).

93 It must be noted that the GST Act uses the term "digital currency" as opposed to "cryptocurrency".

94 Australian Government https://treasury.gov.au/sites/default/files/2019-03/C2016-019_GST treatment_of_digital_currency.pdf (accessed 2019-07-23) 6.

95 S 195-1 of A New Tax System (Goods and Services Tax). 
The definition of digital currency in the Australian GST Act is quite broad and succinctly encapsulates the characteristics of a cryptocurrency. For example, the definition makes it clear that a digital currency can be used as a consideration for a supply. ${ }^{96} \mathrm{~A}$ consideration is any payment in connection with a supply. ${ }^{97}$ Interestingly, the definition of digital currency means that a supply of digital currency is not a financial supply for GST purposes. ${ }^{98}$ If one considers the meaning of digital currency and the meaning of consideration in the GST Act, it is clear that digital currency is treated as "money" for GST purposes. From a GST perspective, "money" includes Australian currency or currency of any other country. ${ }^{99}$

\section{A supply of digital currency}

The term "supply" has a broad definition in terms of the GST Act and includes, inter alia, any form of supply whatsoever including a supply of goods and services. ${ }^{100}$ However, a supply does not include a supply of digital currency unless digital currency is used as consideration for a supply of money or digital currency. ${ }^{101}$ The effect of this provision is that a supply, in relation to digital currency, occurs when digital currency is used as a means of payment for a supply of money and other digital currencies. Thus, there is no GST liability if an Australian resident conducts a sale or purchase of digital currencies. It is important to determine the extent to which an Australian resident will incur GST on the supply of digital currency.

For a transaction to incur GST, that transaction must be a taxable supply for GST purposes. A taxable supply occurs when:

(a) you make the supply for consideration; and

(b) the supply is made in the course or furtherance of an enterprise that you carry on; and

(c) the supply is connected with the indirect tax zone; and

(d) you are registered or required to be registered.

However, the supply is not a taxable supply to the extent that it is GST-free or input taxed. ${ }^{102}$

The effect of this provision is that an Australian resident that carries on an enterprise ${ }^{103}$ in the Indirect Tax Zone ${ }^{104}$ (ITZ) will be rendering a taxable supply if that resident supplies goods and services to another resident. If payment is effected in digital currency, then that transaction will attract GST liability and the Australian enterprise will be required to account for and remit

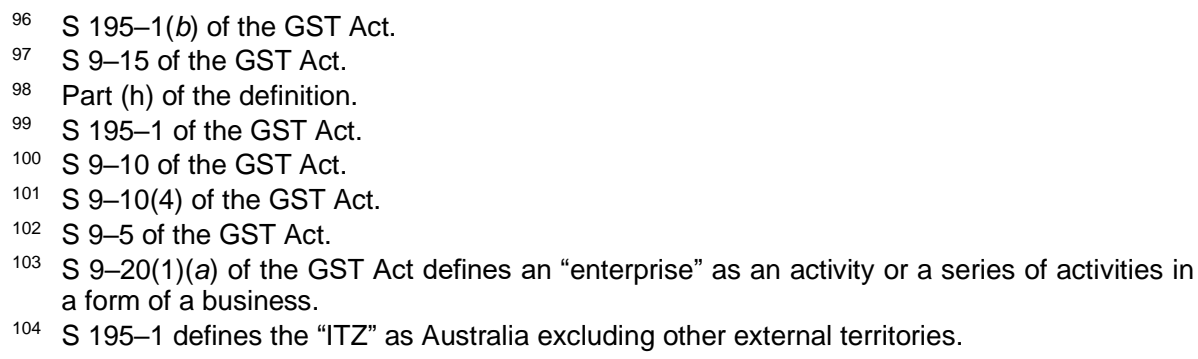


GST to ATO. The amount of GST remitted is the amount of money in Australian dollars. ${ }^{105}$ In the United Kingdom (UK), a similar approach is followed where VAT is due and payable by a person or entity supplying goods and services in exchange for cryptocurrencies. ${ }^{106}$ Similarly, the UK treats cryptocurrency as money for VAT purposes when used as payment for goods and services. The value of the supply of the goods or services is the equivalent of British Pound (BP) value of the cryptocurrency at the time the transaction took place. ${ }^{107}$

In Australia, an Australian business is not liable for GST when using digital currency to pay for goods or services simply because using digital currency as payment has the same effect as using money for payment. ${ }^{108}$ Any supply of digital currency made by an Australian resident to a nonresident will be GST free. ${ }^{109} \mathrm{It}$ is unclear from the literal wording of the GST Act if GST liability accrues where a non-resident supplies goods and services to Australian residents in exchange of payment effected in digital currency. It is submitted that under these circumstances, normal GST rules apply. However, due to the complexities surrounding the cross-border supply of cryptocurrencies, any compliance measures expected from a non-resident would be impractical.

\section{The registration requirement}

In Australia, businesses incur GST liability and are required to register by the GST Act if they carry on an "enterprise" in the Indirect Tax Zone (ITZ) ${ }^{110}$ and the businesses' taxable supplies exceeds an annual threshold of $\$ 75000 .{ }^{111}$ A business is deemed to be carrying on an enterprise if the activity that is been carried is done in a form of business or trade. ${ }^{112}$ It should be noted that section 25-1 of the GST Act uses the word 'must' suggesting that it is a peremptory provision and thus a business does not have discretion in determining when to register for GST purposes.

For example:

105 See ATO "GST and Digital Currency" https://www.ato.gov.au/Business/GST/In-detail/Yourindustry/Financial-services-and-insurance/GST-and-digital-currency/ (accessed 2019-1006).

106 HR Revenue \& Customs "Brief 9: Bitcoin and cryptocurrencies" (2014) https://www.gov.uk/government/publications/revenue-and-customs-brief-9-2014-bitcoinand-other-cryptocurrencies/revenue-and-customs-brief-9-2014-bitcoin-and-othercryptocurrencies\#future-implications (accessed 2019-11-15).

107 Ibid.

108 See ATO https://www.ato.gov.au/Business/GST/In-detail/Your-industry/Financial-servicesand-insurance/GST-and-digital-currency/. (accessed 2019-10-06). It must be noted that an Australian business will be liable for GST if they make a taxable supply and receive digital currency as form of payment.

109 Ibid.

110 The Indirect Tax Zone refers to Australia excluding other territories that fall outside the ambit of the GST.

111 S 23-5 read with s 23-15 of the GST Act.

112 S 9-20 of the GST Act. 
Business $X Y Z$ is an Australian business that trades in fashion clothing and digital currency. Business XYZ's taxable supplies amounts to $\$ 75000$. Of those supplies, $\$ 15000$ consists of digital currency supplies.

In the above example, although the supplies of Business $X Y Z$ exceed the registration threshold, Business $X Y Z$ is not compelled to register for GST purposes because a portion of those supplies emanates from the supply of digital currencies. Similarly, if Business XYZ made sales solely from the supply of digital currency, no GST registration obligation will ensue. Generally, supplies of digital currencies do not attract any GST (input taxed). ${ }^{113}$

\section{Tax invoices}

When submitting a tax invoice to ATO, an Australian business receiving digital currency as payment for a taxable supply must include the GST payable in Australian dollars together with sufficient information that will indicate the price or value of the digital currency. ${ }^{114}$ The tax invoice should also include the conversion rate that the business used in order to work out the GST payable on the specific supply in Australian dollars. ${ }^{115}$

\section{LESSONS DRAWN FROM AUSTRALIA: POSSIBLE SOLUTIONS FOR SOUTH AFRICA}

For South Africa to replicate the Australian GST treatment of digital currency in respect of its VAT treatment of cryptocurrency, the following steps are indicated:

1. A legal definition of cryptocurrencies must be inserted in the VAT Act. This definition should include what does not constitute cryptocurrencies for VAT purposes. The following definition can be used as an example for VAT purposes:

"A cryptocurrency is a digital representation of value used as a consideration for a supply but excludes money."

2. The reference to cryptocurrencies under "financial services" must be removed from section 2 of the VAT Act. For VAT purposes, a sale and purchase of cryptocurrencies should be VAT exempt. If a vendor accepts cryptocurrencies as payment for goods and services, then that transaction should be deemed to be a taxable supply and therefore incurring VAT liability. The vendor or merchant must account for and remit VAT to SARS on that transaction. The use of cryptocurrencies in those circumstances must be treated as a payment for taxable supply insofar as the vendor accepts cryptocurrencies as payment (consideration in money) for goods or services in South Africa. The

113 ATO "Input-Taxed Sales" https://www.ato.gov.au/Business/GST/When-to-charge-GST-(andwhen-not-to)/Input-taxed-sales/ (accessed 2019-07-23).

114 See ATO https://www.ato.gov.au/Business/GST/In-detail/Your-industry/Financial-servicesand-insurance/GST-and-digital-currency/ (accessed 2019-10-06).

115 Ibid. 
merchant or vendor must convert the cryptocurrency equivalent into South African Rand. In South Africa, certain e-commerce businesses like Takealot.com accept bitcoins as a means of payment for goods and services. ${ }^{116}$ The initiative must be supported and driven forward by SARS and National Treasury.

3. The cross-border supply of cryptocurrencies to residents must be VAT exempt. If a resident uses cryptocurrencies as a payment method for goods or services from a non-resident, then that transaction should be VAT exempt. This must be clearly stated for purposes of legal certainty.

4. SARS must publish administrative guidelines that clearly state and describe the VAT treatment of cryptocurrencies for taxpayers. The guidelines should include the relevant information that must be displayed on a tax invoice by merchants and vendors.

\section{$8 \quad$ CONCLUSION}

A juxtaposition of the South African legal framework and the Australian legal framework pertaining to the VAT/GST treatment of cryptocurrencies reveals that the South African legal system has deficiencies when it comes to the VAT treatment of cryptocurrencies. While it is true that there is currently no universal consensus on the classification and definition of cryptocurrencies, this should not deter South African tax authorities and policymakers from inserting a legal definition of cryptocurrencies in the VAT Act. Tax authorities should take cognisance of the fact that technology continuously evolves and having a clear definition of cryptocurrencies has the propensity to encourage compliance amongst taxpayers. The implementation of a flexible legislative framework allows for necessary changes to be made by policymakers when the need arises. ${ }^{117}$ For these reasons, it is suitable to insert a legal definition in published Regulations to the VAT Act.

This article has shown that transactions involving cryptocurrencies can be treated as a taxable supply. If one considers that VAT is the most important and reliable source of revenue for states, ${ }^{118}$ the VAT system should consistently be used as an avenue to generate revenue. Tax authorities must publish guidelines in instances where cryptocurrencies will be treated as a taxable supply. One of the most fundamental aspects of any VAT system is its administration. ${ }^{119}$ If the administrative guidelines pertaining to the VAT treatment of cryptocurrencies is lacking, a taxpayer's tax obligation may be non-existent. Tax authorities should aim to provide as much information as possible to taxpayers to enable the latter to meet their tax obligations. ${ }^{120} \mathrm{Bal}$ correctly points out that any information provided to taxpayers should be easily accessible and formulated in a language that a

116 See www.iol.co.za/business-report/watch-what-can-you-buy-with-bitcoin-in-south-africa12208261 (accessed 2019-10-09).

117 Bal 2019 Intertax 226.

118 Gendron "Real VATs vs the Good VAT: Reflections From a Decade of Technical Assistance" 2017 32(2) Australian Tax Forum 259259.

119 Ebrill et al The Modern VAT 141.

120 Ibid. 
reasonable taxpayer can understand. ${ }^{121}$ The guidelines must clearly explain, by means of practical applicable examples, the nature and extent to which taxpayers will incur VAT liability when dealing with cryptocurrencies.

In conclusion, this article has identified an area for the fiscus to broaden the tax base. Considering that SARS recently recorded a revenue shortfall, ${ }^{122}$ it is submitted that treating cryptocurrencies transactions as a taxable supply is one way of addressing revenue shortfall.

121 Bal 2019 Intertax 228.

122 See Mail \& Guardian "Tax Revenues Record Shock Decline” https://mg.co.za/article/2019 04-01-tax-revenues-record-shock-decline (accessed 2019-10-07). 